\title{
Factors Affecting the Road Safety
}

\author{
Lenka Komackova and Milos Poliak \\ Fakulta prevádzky a ekonomiky dopravy a spojov, Katedra cestnej a mestskej dopravy, Univerzitná 1, 010 26, Zilina
}

\begin{abstract}
The road safety is all - society issue not only in European Union, but in non-European countries, too. The number of fatalities per 100, 000 inhabitants is the value higher than two persons per a year, depending on the member state of European Union. Many authors agree, e.g., Koornstra et al. or Wegman and Oppe, that road safety is improving because the number of fatalities is decreasing. The number of road accidents and mainly the number of fatalities represents much higher number than is the aim of the strategic documents of European Union. It is necessary to find solutions for increasing the road safety. The aim of this paper is to analyse factors affecting the road safety and to identify another possibilities for increasing the road safety.
\end{abstract}

Key words: Road safety, driver, accident.

\section{FactorsAffectingtheRoadSafety}

Many factors influence the road safety. The most important factors are driver behaviour, construction and condition of the vehicle and condition of infrastructure. The Fig. 1 narrowly defined factors by the mean causal network. The causal network has three levels: the first level concerns global factors such as demographic structure of the population, which influence at the second level the states of the triad, in order from left to right: host as the road user, environment as the infrastructure and the traffic conditions, and the vehicle. At the third level, interactions of these components lead under the major influence of speed to crashes and injuries, which could be minor, severe or fatal.

On the ground of extensive analysis, Evans [1] says, that all factors are important but nowadays the most important factor is driver behaviour because of the consecutive building highways. Evans [1] analyses the relationship between vehicle construction and quality of infrastructure. Improving quality of infrastructure is generally understood as producer of major benefits in terms of reducing risk [1].

Corresponding author: Lenka Komackova, Ing., research fields: transport economics and road safety.

\subsection{The Change in Quality of Infrastructure}

Transport engineering and operating characteristics of the road network provide conditions for increase the road safety [2]. Elvik et al. [3] classified the safety initiatives of transport engineering in terms of road design, road maintenance and management [3]. Elvik et al.[3] found out that in global research of road engineering, the best safety advantage/investment costs are from separated transport (according to the direction and type of the vehicle); from improved crossroad design and its management (turning left, canalization, roundabouts at selected locations); check of black spot and improved signalisation. The biggest safety advantages are remaining friction of the road and good road maintenance during the winter, mainly control of ice and snow. The influence of road safety network is possible to define as indicator of road network safety performance, which is based on quantitative methodology for assessment of road network and qualitative aspects for the proposal of road safety at a regional level, according to the Dutch study [5]. The aim of indicators of road network safety performance is to measure whether right road is located at the right place. It is defined as the percentage of appropriate actual road category length, per road category, which can be mathematically expressed as: 


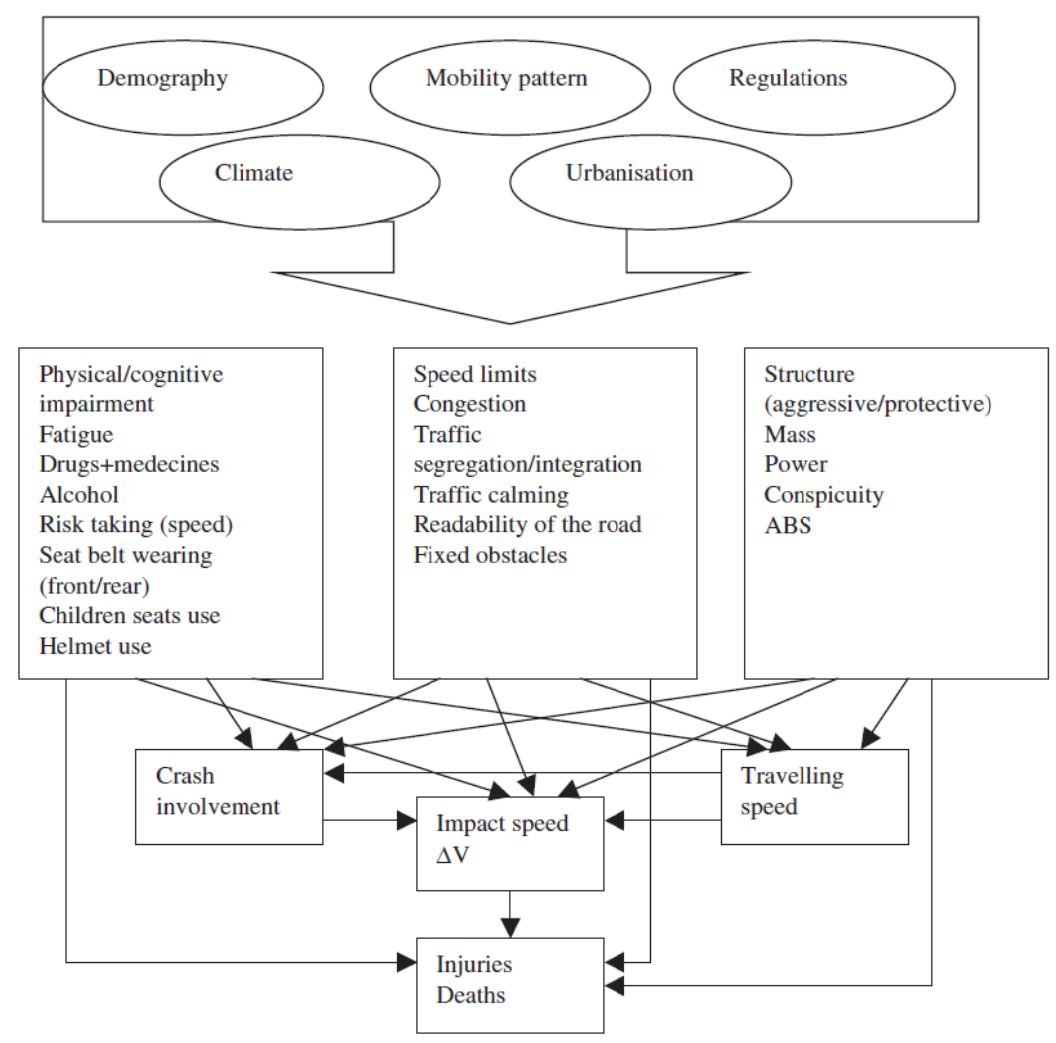

Fig. 1 Causal web diagram of risk factors in traffic accident injuries Reference: [4].

$$
\operatorname{SPI}\left(\mathrm{T}_{\mathrm{i}}\right)=\frac{\sum_{\mathrm{n}}\left(\mathrm{L}_{\mathrm{ti}}^{\mathrm{Ti}} / \mathrm{ti} \geq \mathrm{Ti}\right)}{\left(\sum_{\mathrm{n}} \mathrm{L}_{\mathrm{ti}}^{\mathrm{Ti}}\right)}
$$

where:

- $\mathrm{T}_{\mathrm{i}}$ is the theoretically required road category $\mathrm{i}$ : $\{$ sic categories, from AAA to $\mathrm{C}\}$;

- $\mathrm{t}_{\mathrm{i}}$ is the actual road category $\mathrm{i}$ : $\{$ six categories, from AAA to $\mathrm{C}$ \};

- $\mathrm{n}$ is the number of road connections;

- SPI $\left(\mathrm{T}_{\mathrm{i}}\right)$ is the value of the safety performance indicator for road category $\mathrm{T}_{i}$;

- $\mathrm{L}_{\mathrm{ti}}^{\mathrm{Ti}}$ is the actual road length, which should theoretically be of category $T_{i}$ and actually is of category $t_{i}$.

With the decreasing, value of SPI $\left(\mathrm{T}_{\mathrm{i}}\right)$ increases the risk of an accident. If it is not possible to increase road network category, it is necessary to find solutions for decreasing traffic flow density that is in the Fig. 2. In Fig. 2 there is the relationship between traffic flow densities $\mathrm{Q}$, accident density $\mathrm{r}$ for individual road categories $\left(T_{1}\right.$ - the worst, $T_{2}$ - the best). In Fig. 2, there is the maximum level of accident where is necessary to increase the road category (e.g., at the point of $\mathrm{Q}_{1}$ it is necessary to increase road category from $T_{1}$ to $T_{2}$ ). If it is not possible to increase the road category, it is necessary to find solutions for decreasing traffic flow density without limiting the transport flow density. As the only effective solution is the support of public transport.

\subsection{Vehicle Safety}

Vehicle design and performance have two potential effects on safety: first, those aimed at reducing the risk of crashing; second, those aimed at reducing the consequences when accidents do occur.

Vehicle mass, size and speed have long been important concerns for manufacturers and for safety analysts. When accidents occur, vehicle mass and speed are the two most important aspects determining accident severity and risk. Fatality risk depends strongly on the ratio of the masses of the vehicles; if 


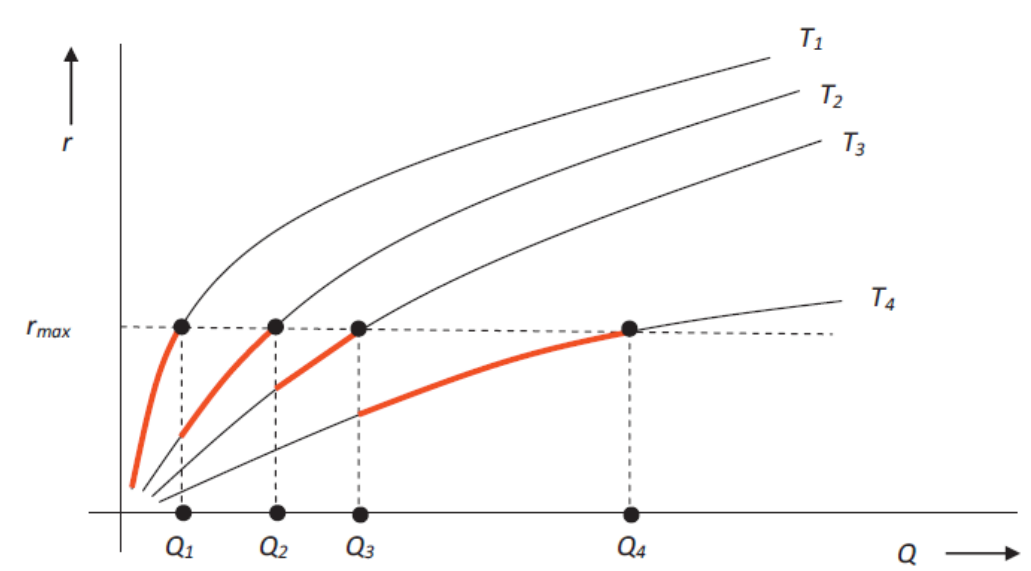

Fig. 2 The relationship between road accident density, $r$, and traffic volume, $Q$, for different road types, $T$ Reference:[6].

one car is half as heavy as the other is, the driver in the lighter car has approximately twelve times the fatality risk [7].

Accidents by nature involve rapid reductions in speed, and because vehicle occupants continue to move at the prior speed, occupancy protection devices are intended to reduce the likelihood and severity of impact, and to prevent ejection. Both the integrated seat belt and shoulder harness, and even the basic safety belt, have been shown to be associated with major reductions in fatality risk [8]. In addition, airbags have been shown to be most effective when used in conjunction with seat belts.

\subsection{Driver Behaviour}

Driver performance and driver behaviour are the biggest challenge to improving the road safety [9]. Research literature finds strong safety effects for increased use of seat belts, and control of speed. Driver education has little impact on safety. While better awareness and increased enforcement of drunk driving laws has improved safety [10]. As Evans notes: "The basic skills to stop, start, and steer the vehicles are acquired remarkably easily and quickly. Complex higher level skills that are acquired only after many years of experience can contribute to reducing crash risk." On the ground of analyse of factors affecting the road safety it is necessary to deal with driver, driver behaviour, and driver skills.

\section{TheRelationshipbetweenDriverBehaviour and Road Safety}

With support of public transport, it is possible to decrease the traffic flow density so more passengers will be transported by public transport. However, it is possible to increase the road safety so the number of professional drivers will be higher than number of nonprofessional drivers. It is possible to show results of research which was in the Slovak Republic from 2010 to 2013. In Table 1, there are the number of accidents, the number of fatalities and transport performance of vehicles. With an average transport performance, " $z$ " happened " $x$ " accidents, in which " $y$ " number of persons lost life per year in average.

In case of bus transport, the average transport performance "c" caused "a" accidents per a year, where "b" passengers lost life.

It is necessary to state, that bus drivers cause a little part of accidents (which involves buses). In Table 3, there is the list of bus drivers' accidents. Of the total number of bus accidents, it is only $19,51 \%$ accidents caused by bus drivers.

If we consider the simplified approach, it is possible to state, that bus transport is more safety than automobile transport. In Tables 4 and 5, there is the likelihood of accident and fatality in automobile transport and bus transport.

To an increase in the share of buses would improve the value of the following factors: 
Table 1 The comparison of the number of accidents and fatalities in relation to the realized transport performance in automobile transport.

\begin{tabular}{llllll}
\hline Automobile transport & 2010 & 2011 & 2012 & 2013 & Average \\
\hline The number of accidents & 11,494 & 8,558 & 7,406 & 7,640 & $\mathrm{x}$ \\
The number of fatalities & 75 & 106 & 88 & 145 & $\mathrm{y}$ \\
Transport performance [million seat - kilometre] & 26,879 & 26,887 & 26,935 & 27,155 & $\mathrm{z}$ \\
\hline
\end{tabular}

Reference: [11].

Table 2 The comparison of the number of accidents and fatalities in relation to the realized transport performance in bus transport.

\begin{tabular}{llllll}
\hline Bus transport & $\mathbf{2 0 1 0}$ & $\mathbf{2 0 1 1}$ & $\mathbf{2 0 1 2}$ & $\mathbf{2 0 1 3}$ & Average \\
\hline The number of accidents & 164 & 95 & 84 & 82 & $\mathrm{a}$ \\
The number of fatalities & 0 & 0 & 0 & 3 & $\mathrm{~b}$ \\
Transport performance[million seat - kilometre] & 4,436 & 4,611 & 4,584 & 4,388 & $\mathrm{c}$ \\
\hline
\end{tabular}

Reference: [11].

Table 3 Bus accidents in Slovak Republic in 2013.

\begin{tabular}{lll}
\hline & Accident caused by bus driver & Bus driver involved in accident \\
\hline Bratislava Region & 0 & 4 \\
Trnava Region & 2 & 3 \\
Trenčín Region & 6 & 12 \\
Nitria Region & 1 & 4 \\
Žilina Region & 4 & 17 \\
BanskáBystrica Region & 1 & 11 \\
Prešov Region & 2 & 12 \\
Košice Region & 0 & 3 \\
Total in SR & $\mathbf{1 6}$ & $\mathbf{6 6}$ \\
\hline
\end{tabular}

Reference: authors.

Table 4 Proportional share between the number of accidents and the number of passengers in automobile transport.

\begin{tabular}{llllll}
\hline The year & $\mathbf{2 0 0 9}$ & $\mathbf{2 0 1 0}$ & $\mathbf{2 0 1 1}$ & $\mathbf{2 0 1 2}$ & $\mathbf{2 0 1 3}$ \\
\hline The number of automobile accidents & 15,298 & 11,494 & 8,558 & 7,406 & 7,640 \\
The number of passengers in automobile transport & $1,846,439$ & $1,859,479$ & $1,875,789$ & $1,894,167$ & $1,900,418$ \\
& 0.0000083 & 0.0000062 & 0.0000046 & 0.0000039 & 0.0000040 \\
\hline [thousand people] & & &
\end{tabular}

Reference: authors.

Table 5 Proportional share between the number of accidents and the number of passengers in bus transport.

\begin{tabular}{llllll}
\hline The year & $\mathbf{2 0 0 9}$ & $\mathbf{2 0 1 0}$ & $\mathbf{2 0 1 1}$ & $\mathbf{2 0 1 2}$ & $\mathbf{2 0 1 3}$ \\
\hline The number of bus accidents & 194 & 164 & 95 & 84 & 95 \\
The number of total passengers in bus transport & 323,142 & 312,717 & 299,579 & 289,228 & 270,123 \\
[thousand people] & 0.0000006 & 0.00000052 & 0.00000032 & 0.00000029 & 0.00000035 \\
\hline
\end{tabular}

Reference: authors.

The physical condition of the driver - the drivers of the bus have set out the conditions for the implementation of travel (e.g., regulation (EC) No. 561/2006) according to which, after a specified time of driving must draw the rest. For passenger vehicles, the driver is not limited to the time of driving, which for long driving affects the reaction times of the driver and increases the likelihood of a car accident. 
Psychological condition of the driver-the drivers of the bus attend regular psychological checks. Given that the driver of a personal vehicle after the issuance of a driving licence does not have to go through such checks, it is possible to assume that the drivers of the bus are in a better mental condition.

Use of drugs, drugs and alcohol - the drivers of the bus at the beginning of their working shift are checked regularly or randomly on the ingestion of alcohol or other narcotic substances. The driver is also under the control of the driving of the vehicle through the online equipment of the vehicle or even the camera. Therefore, it is significantly less likely that drivers will drive under the influence of alcohol.

Risky driving - the drivers of the bus are drivers, who have higher experience with the management of vehicles and are better able to respond in risky situations. The drivers of the buses are regularly trained on the way of safe driving with your vehicle; therefore, it can be assumed that the technique of driving the driver is safer when compared to the average technique driving other drivers. In the case of a risky ride, it is possible to expect the reaction of the passengers [12].

\section{UsingAlcohol as IndividualComponent of DriverBehaviour}

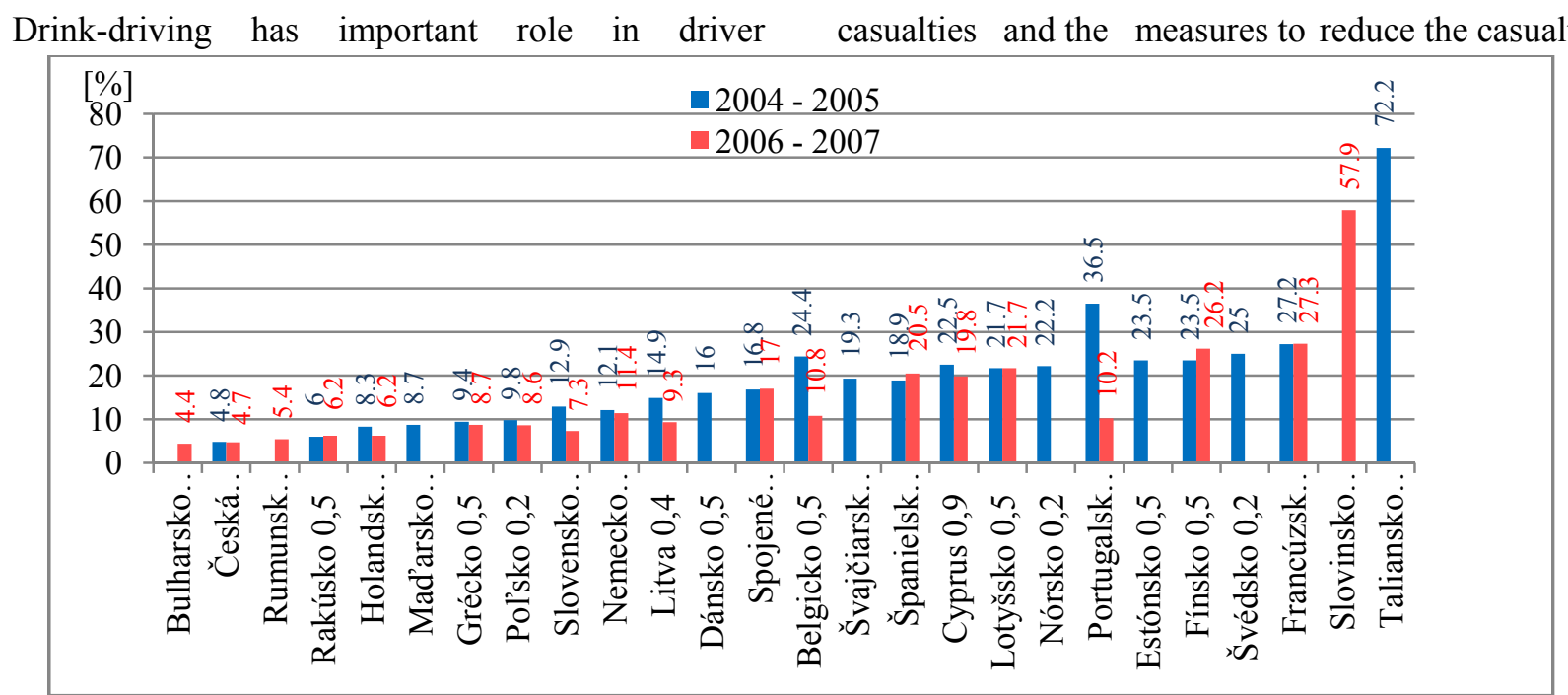

behaviour. Ramsted and Skog show that there is a correlation between the overall alcohol consumption in countries or states and fatal accident rates although this correlation varies between different regions of the world and between the genders and age groups. An increase of 11 of pure alcohol per inhabitant 15 years and above, increases motor vehicle fatalities per 100,000 inhabitants for men by 0.05 in Northern Europe; 2.1 in Central Europe and 0,8 in Southern Europe and by 3.2 in the US and 3.6 in Canada. For women the increase in motor vehicle fatalities is generally smaller than for men. Sheehan [13] shows parallel trends for alcohol consumption and percentage of fatally injured drivers and motorcycle riders with a BAC of $0.5 \mathrm{~g} / 1$ or greater for Queensland, Australia for 1982-2005.

The influence of drink-driving on road safety is possible to define by Safety Performance Indicators. Gitelman [14] defines SPIs: SPIs are the measures (indicators), reflecting those operational conditions of the road traffic system, which influence the system's safety performance [14], i.e., an SPI may be described as a measurement of a factor causally related to crashes or casualties. SPIs are used in addition to the accident and casualty statistics to indicate safety performance or to understand the process that leads to accidents. They also provide the link between the road casualties and the measures to reduce the casualties.

Fig. 3 Alcohol SPI for safety net 2004-2005 and ETSC (2007).

Reference: Safety Performance Indicator for alcohol in road accidents -International comparison, validity and data quality. 
SPIs may also show information about basic accident causalities. They may concern groups of road users, e.g., children, new drivers or professional drivers, or compliance of rules safety, e.g., using safety belts, or they cover specific areas like urban road network or Trans-European network.

In Fig. 3, there is SPI for some states. SPI shows how big the share of drink - driving to the accident is. The countries have average SPI for the two periods. The legal BAC-limit in each country is indicated in brackets above the country name. The BAC-limit of 0 . $3 \mathrm{~g} / \mathrm{l}$ for Germany is a special limit for accident-involved drivers. The general limit for Germany is $0.5 \mathrm{~g} / \mathrm{l}$. The BAC-limit for Cyprus was changed from $0.9 \mathrm{~g} / 1$ to $0.5 \mathrm{~g} / 1$ in 2006 .

The research states that it is possible to control a very small part of drivers despite of the fact that drink-driving increases the number of accidents. It is possible to control drivers in public transport before starting the work shift. By the increasing share of bus drivers, it is possible to decrease the value of SPI before driving.

\section{Conclusion}

Nowadays, methods of increasing the road safety are intended on increasing the road infrastructure quality or regulation of road traffic within the boundaries of the city. The increasing road infrastructure quality increases the road safety. On the other side, the increasing road infrastructure quality increases the attractiveness of automobile transport [15]. The increasing number of individual automobiles and the increasing traffic density increase the risk of accident. The new point of view for increasing the road safety is to keep or increase the number of passengers in public transport. It is necessary to find new ways, how to solve the situation of increasing the road safety and economic sustainability of bus transport. By support of bus transport, it is possible to transport passengers with drivers with lower likelihood of accident. On the other side, traffic density which increasing the road safety will be lower. It is possible to say that the support of bus transport has multiplier effect to the relation of increasing the road safety.

Tento príspevok bol spracovaný $\mathrm{s}$ podporou: MŠVVŠ SR - VEGA č. 1/0320/14 POLIAK, M.: Zvyšovanie bezpečnosti cestnej dopravy prostredníctvom podpory hromadnej prepravy cestujúcich.

\section{References}

[1] Evans, 1. 2004. Traffic Safety. Bloomfield Hills, MI: Science Serving Society.

[2] A New Theory of ComplexityforSafetyResearch. TheCase of Long-LastingGap in Road SafetyOutcomesbetweenFrance and Great Britain.

[3] AASHTO, 2010. Highway Safety Manual. Washington: AASHTO.

[4] http://www.eu-portal.net/material/downloadarea/kt3_wm sk.pdf.

[5] http://www.uvzsr.sk/index.php?option=com_content\&vie $\mathrm{w}=$ article \&id=1852:globalna-sprava-onstave-bezpenosticestnej-premavky-2013\&catid=145:urazovos-deti.

[6] Road Safety Performance Indicators for the Interurban Road Network.

[7] Davis, G. A.2000. "Accident Reduction Factors and Casual Inference in Traffic Safety Studies: A Review." AccidentAnalysis and Prevention 32 (1): 95-109.

Evans, 1.2004. TrafficSafety. BloomfieldHills, MI: ScienceServing Society.

[8] Cohen, A., and Evans, L. 2003. "The Effects of Mandatory Seat Belt Laws on Driving Behaviour and Traffic Fatalities." Review of Economics and Statistics 85 (4): 828-43. National Highway Traffic Safety Administration (December 2000). Fatality Reduction by Safety Belts for Front-Seat Occupants of Cars and Light Trucks. Report DOT-HS-809-199. Washington: NHTSA. National Highway Traffic Safety Administration (2010a). Livessaved in 2009 by Restraintuse and Minimum-dringing-Agelaws. Washington (DC):NHTSA.

[9] Shinar, D. 2007. Traffiic Safety and Human Behaviour. Bingley, UK: Emerald Group Publishing.

[10] U. S. Centers for Disease Control and Prevention. 2011. Impaired driving.

[11] Ramstedt, M. 2008. Alcohol and Fatal Accidents in the United States-A Time Series Analysis for 1950-2002. Accident Anal. Prev. 40, 1273-128; Skog, O. J. 2001. Alcohol Consumption and Mortality Rates from Traffic Accidents, Accidental Falls, and Other Accidents in 14 
European countries. Addiction 96, S49-S58.

[12] Sheehan, M. 2006. Impaired Driving. Road safety summit. http://www.transport.qld.gov.au/Home/Safety/Road/Rs summit.

[13] Hakkert, A. S., Gitelman, V., and Vis, M. A. 2007. "Road Safety Performance Indicators: Theory." Presented at the Deliverable D3. 6 of the EU FP6 project Safety Net.
[14] Zhou, L., Burris, M. W., Baker, R. T., and Geisel brecht, T. 2009. "Impact of Incentives on Toll Road Use by Trucks, TransportationResearchRecord." Journal of the Transportation Research Board, No. 2115. Washington, D. C.

[15] http://www.telecom.gov.sk/files/statistika_vud/preprava osob.htm 9.7.2015 Prezídium policajného zboru. 